\title{
Understanding Students Learning Style and Their Performance in Computer Programming Course: Evidence from Bruneian Technical Institution of Higher Learning
}

\author{
Afzaal H. Seyal, Yeo Sy Mey, Mardiyah Hj Matusin, Hjh Norzainah Hj Siau, and Armanadurni Abdul \\ Rahman
}

\begin{abstract}
This pioneering study investigates the students' learning style in understanding their performance in computer programming course where they enroll for their first year of Bachelor of Internet computing degree program. The data was collected from cohort of students who appeared for their first year examination in programming concept module and were given Kolb inventory of learning style. The result through Chisquare test confirmed that there existed a relationship between learning test and students' performance in programming module. Moreover, students with converging and assimilating learning styles are significant and are closely associated with their pass or credit grade. Based upon the results, some recommendations were made in order to enhance teaching and learning programming.
\end{abstract}

Index Terms-Brunei darussalam, computer programming, kolb learning style, technical institutions.

\section{INTRODUCTION}

Teaching and Learning the computing in general and computer programming in particular, have undergone radical changes especially in the last decade of last millennium. The advent of new object-oriented programming languages such as $\mathrm{C}, \mathrm{C}++$ or Java has changed the need of computer industry. Moreover, the advancement in portable computing power, and the computing environment have brought a shift in software applications. Unfortunately, the increase in computing power with more sophisticated tools the computing productivity especially in the domain of computer programming has significantly decreased the students' learning capability towards these advanced procedural and object-oriented languages. This trend is noticeable among the major technical institutions that offer diploma and first degree in computer science as well as computing and information systems. Lenox et al. [1] studied the declining cause of students' interest in CS/IS/IT and identified the top three reasons for the decline. He had found that $67 \%$ was due to the outsourcing of CS/IS/IT jobs,

Manuscript received March 9, 2014; revised May 19, 2014. This study was a part of Science \& Technology funded research project sponsored by the Department of Economic Planning \& Development (JPKE), Prime Minister's Office Brunei Darussalam, under the Grants JPKE/DOIM/RKN 922/41/4 TP

Afzaal H. Seyal is with the Faculty of Business \& Computing, Institut Technologi Brunei, Brunei (e-mail: afzaal.seyal@itb.edu.bn).
$49 \%$ of it was because of dot.com failure and $45 \%$ showed decline in students' analytical and programming ability. Gupta and Houtz [2] studied high schools students' perception of information technology skill and asked students about 'what skills do they think are necessary for a career in IT' Out of four different types of skills, the programming was ranked third from the top. Dunning et al. [3] pointed out that lack of awareness of programming skills arose because poor performance, this not only deprived the students to produce correct responses but also of the expertise to produce the desired output. McKenzie [4] suggested that the redesigning the computer science/IS curriculum and this redesign should reflect the external factors that drove the curriculum revision and must target the area in (1) improving the interest and (2) providing answer for certification issues. Similarly, Lockheed and Mandinach [5] emphasized that computing should include integrated approach by focusing on teaching application software skills. Lister and Leaney [6] suggested an approach to improve the teaching and learning as two-fold approach. First, they used a criterion-referenced approach where fundamentally different tasks were set according to the ability of the students. Secondly, they suggested of adopting learning strategy for the weaker students that simply required demonstrating knowledge and comprehension and the ability to read and understand programs. For the average students they must focus on attempting traditional tasks of maintaining the existing programs and finally for the good students they must focus to do set open-ended tasks on the developing, synthesizing and evaluating the tasks.

The above cited examples further endorsed that students' performances in learning computer programming is declining and academics and researchers are pointing out in their studies [7] Some of them suggested the change in curriculum and in teaching-learning strategies. $\mathrm{We}$ understand that in today's globalized world knowledge is well supported at various domains [8] and a typical learning situation has changed from old talk and chalk method to the interactive and active learning. Some studies in particular suggested that students' academic achievements were highly related to their learning styles [8], [9]. We also understand that every individual has his distinctive learning style, characteristics, strength and preferences in which he feels comfortable with his own learning and process information [10]. In knowing students' learning styles can help to enhance learning and teaching [11].

The diversity in teaching and learning styles has begun to 
gain more attention as many studies match their preferred learning styles [12-[14]. These studies have pointed out that it is vital for instructors or teachers to have awareness of their learners' needs, capacities, potentials and learning styles preferences in order to have effective classroom teaching and learning. Yilmaz-Soylu and Akkoyunlu [9] noticed that though all human beings had common biopsychological and social characteristics in learning process, yet individual preferences concerning on the ways of giving meaning and acquiring information may vary. Therefore the information which becomes the subjective life of an individual after giving being processed may have individualspecific differences in ensuring his way of learning and remembering. For such specific reasons, it is important to study the students' learning style to understand the teaching/learning process.

Learning style therefore is defined as the "composite of characteristics; cognitive, affective and physiological characters that serve as relatively stable indicators on how a learner perceives, interacts with and responds to his learning environments" [15]. Therefore several learning styles were reported in the literature such as categorized as sensory like VARK model [16] and cyclical such as Kolb's Learning Styles Inventory (KLSI) [17], Honey and Mumford [18] learning style theories, Felder-Silverman Index of Learning Style (LSI) model ([19]. Another model is the Myers and Briggs Type Indicator (MBTI) [20] which was based upon the personality type. However, Allert [21] stated that there were two dominant learning style assessment tools used in science and engineering education. For Kolb's KLSI and Felder-Silverman's (LSI), both these models measured four different dimensions of an individual's learning style. Therefore we have selected for this study the Kolb's KLSI simply because that instrument was very simple and did not ask on lengthy questions like LSI that had 44 questions, i.e. 11 for each of the four dimensions. KSLI took only five minutes to fill-in the desired response. We agree to the arguments as stated by Campbell and Johnstone [22] and Mainemelis, Boyatzis and Kolb, [23] and we are in favor of using KLSI that suggested that instrument had also been used in a number of other studies that provide for useful comparison. Loo [24] also suggested that this instrument remained effective to study students' learning style among tertiary students.

\section{Kolb Learning Style Theory}

Kolb [17] published his learning styles model from which he developed the learning style inventory (LSI). Kolb's experiential learning theory worked on two-levels: a four stage cycle of learning and four separate learning styles. Much of Kolb's experiential learning theory was concerned with the learner's internal cognitive processes. Kolb stated that learning involved the acquisition of abstract concepts that could be applied flexibly in a range of situations. Kolb [17] believed that learning was the process where knowledge was created through the transformation of experience. His experiential learning style theory was typically represented by a four stage learning cycle in which the learner 'touches all the bases'. He theorized that four combinations of perceiving and processing determine four learning styles that made up a learning cycle. These were: 1)
Concrete experience (CE) (feeling) which was either a new experience of situation faced or a reinterpretation of existing experience, 2) Reflective observation (RO) (watching) to notice any inconsistencies between experience and understanding, 3) Abstract conceptualization (AC) (thinking) where thereflection could create new ideas or modification of an existing abstract concept, 4) Active experimentation (AE) (doing) where learner applied them to the world around him to see the results. Based upon these four, Kolb set out four distinct learning styles that made up a learning cycle.

Diverging (Feeling \& Watching-CE/RO). Learners with this style are able to look at things from different perspectives which are sensitive and they prefer to watch rather than do, or tend to gather information and then use their imagination to solve problems. Kolb called this style 'diverging' because these learners performed better in situations that required ideas-generation like brainstorming. The learner with this style prefers to work in groups, to listen with an open mind, tend to be imaginative with emotions and strong in the arts. This kind of learner has broad cultural interests and likes to gather information.

Assimilating (Watching and thinking-AC/RO). Learners with this style prefer concise and logical approach. Ideas and concepts are more important than people, feelings and/or emotions. This kind of learner requires good clear explanation rather than practical opportunity. He is more attracted to logically sounded theories than approaches based on practical value. This style of learning is more commonly related to information technology and science career. Learners prefer readings, lecturers, exploring analytical models and having time to think things through.

Converging (Doing and thinking-AC/AE). Learners with this style like to solve problems and use their learning to find solutions to practical issues. They prefer technical tasks and are less concerned with people and interpersonal aspects. These learners are best at findings practical uses for ideas and theories. They focus on solving problems and make decisions by finding solutions to questions and problems. The converging learning style produces specialists with technology abilities.

Accommodating (Doing and feeling-CE/AE). Learners with this style rely on intuition rather than logic. These learners use other people's analysis, and prefer to take a practical, experimental approach. They are attracted to new challenges and experiences, so they carry out plans.

Fleming [25] on the other hand, pointed out that the learning styles are beneficial to learning; however, there is not much evidence that knowledge of one's learning style is beneficial to learning but it does not mean that benefit does not exist. So lack of evidence does not mean that we don't have many reliable and valid researches that would predict knowing one's learning is beneficial for learning. This further indicates that there exists a gap in knowing the learning style of the learners and types of benefits it brings to the improvement of knowledge in teaching/learning phenomenon. There is strong need for researchers to conduct more and more studies in this domain that will bring further evidence to confirm to the suitability of knowing one's learning style to the overall academic performance and to promote the knowledge. The present 
study is therefore conducted in technical institutions of Brunei Darussalam with these specific objectives.

\section{Objectives of this study are:}

1) What aspect of learning style can be found in typical computing students?

2) What is the influence of the students' learning styles on their performance in the course?

3) What is the relationship between gender and students' learning styles?

4) How can the results of the study be effective in designing the teaching/learning pedagogy?

\section{REVIEW OF PREVIOUS STUDIES}

\section{Learning Style and Student Achievements in Programming Course}

Learning style in literature can also be referred to as "cognitive style". James \& Blank [26] suggested the existence of different dimensions with learning styles. Several researchers had attempted to investigate the learning style with the higher grade achievement in computer programming [27][28][29]. Alumran, [30] found that the information technology students were found to be more active learners than the science students and law students measured by learning style index. Yusof, Othman and Karim, [28] conducted a quasi-experimental study using Kolb's learning cycle and found no significant interaction effect between learning style and treatment toward student achievement. Wing and Hoi, [29] found that there were statistically significant learning style group effects on student achievement in programming using Gregorc Style Delineator (GSD) [30] learning style.

Similarly, Rasmussen and Davidson-Shivers, [31]; Bostrom, Olfman and Sein, [32] and Wu, Dale and Bethel [33] all have reported that convergers and assimilators individuals are successful in learning computers and programming. Ben-Ari [34] and Machanick [35] investigated the cognitive and social aspects of learning leading to a greater understanding of students' preferences and performance in computer science education Campbell and Johnstone [22] studied student's learning style and their achievement in their first year programming class using Kolb model. It showed a significant difference between the abstract and concrete thinkers. Their study confirmed that abstract thinkers (convergers and assimilators) performed better in examination than concrete thinkers (accommodators and divergers). Alharbi et al. [36] investigated the learning style and self-regulated learning strategies for computer science students and found that students' learning styles had a significant impact on academic performance in mid-term examination. Yeboah and Sarpong [37] studied, in Ghana, students' learning styles and higher grade achievement in computer programming based on Kolb-LSI. They found that divergent learners had higher grade achievement in computer. That study further confirmed that there was a significant mean difference of learning style and the convergent learners benefitted less in terms of grades. In addition, studies were conducted in finding the relationship between genders and learning styles. Saverins and Ten Dam [38] performed a meta-analysis of the gender effect using Kolb's LSI and found significant gender preferences on subscales of the instrument. Men rather than women tended to prefer abstract conceptualization (thinking) mode of learning in Kolb's instrument. W-Fat [39] studied the relationship among gender, learning style and programming performance in Hong Kong by using GSD scale and found that gender and dominant learning styles were associated. Contrary to this, Wei, Hoo and See [40] found that gender had a significant influence on students' achievement. Wang and Chen [41] in Australia studied the students' learning style and gender using Kolb-LSI and found that for programming comprehension performance, the convergers performed better than divergers. For high gender consciousness learners, the convergers performed better than divergers.

Norwawi et al. [42] had classified students' performance in computer programming course according to learning style. They used Felder-Silverman's index of learning style [43] and found that a student's good performance in programming course was based on visual, active and sequential learning styles which were equivalent to $\mathrm{EC} / \mathrm{RO}$ and AE/CE of Kolb's LSI. Thus it further indicated the divergers and accommodators. Similarly, D-Silva Carmo et al. [44] studied the impact of learning styles in introductory programming learning by using Felder-Silverman model and verified the differences on the active/reflective, visual/verbal and sequential/global dimension.

From the above discussion, it is clear that there is inconsistency not only in the research findings but also on the use of the learning styles inventory. Therefore, it is significant to conduct more studies on the learning styles to fill-in the gap in the literature. This research will therefore attempt to fill-in the gap and it also highlights new dimensions to the existing repository of knowledge.

\section{Methodology}

\section{A. Design of Instrument}

The research instrument used in this study consisted of two parts. Part A includes students' demographical information including questions asking their result in first year programming final examination, the self evaluation of programming skills, as how much time spent per week in practicising programming, difficulties faced in learning programming and self identifying weaker areas in learning programming. It used the Likert scale starting 1 for strongly disagree to 5 as fully agreed. Part B covered the learning style scale developed by Kolb [17] and consisted of 12 statements. Each statement had four items (A, B, C, D). The learners were asked to rate each item from 4 to 1 corresponding to how well the statements described them (4 indicated the best fit, 3 indicated some fit, 2 indicated seldom fit and 1 the least fit). The sums of item A, B, C and $\mathrm{D}$ were the scores of concrete experience $(\mathrm{CE})$, reflective observation (RO), abstract conceptualization (AC) and active experimentation (AE), respectively. The difference between $\mathrm{AC}$ and $\mathrm{CE}$ represented the higher preference of active experimentation or concrete experience, whereas the difference between $\mathrm{AE}$ and $\mathrm{RO}$ represented active experimentation or reflective observation. Thus in this study 
participants were identified as the divergers, assimilators, convergers and accommodators from the perspective of the above learning styles [41] as shown in Table I. The learners with diverging style preferred watching and feeling, assimilators solved problems by using inductive reasons and abilities to create theoretical models, convergers solved problems by thinking and doing and relied heavily upon hypothetical deductive reasoning focusing on specific problems and finally the accommodators solved problems by carrying out plans and experiments and adaptive to specific immediate circumstances.

\section{B. Reliability and Validity of Kolb LSI}

The study has found that Kolb LSI is sufficiently reliable especially after the changes (LSI version-3, 1999 version) in the original instrument since its early version of 1984 as pointed out by Coffield et al. [45]. The construct validity of the LSI has been questioned as it possessed a low predictive validity when LSI initially was developed as a selfassessment exercise [45]. Despite the counter-claims regarding validity the Kolb model remains popular nonetheless; possibly because it was the first model to be widely disseminated.

\section{Sampling}

Seventy students of our Bachelor of Internet Computing were selected for this study and their results for first-year programming module were used. The sampling of the population is not a new technique. Total population sampling is a type of purposive sampling techniques that involves examining the entire (total) population that has a particular set of characteristics, traits, experiences, knowledge and skills of an event [46].

\section{DATA ANALYSIS AND RESUltS}

The data collected in this study were analyzed by using SPSS software version 19 for conducting descriptive statistics, chi-square test and non-parametric correlation test. Table I shows the demographical and other necessary data used in the questionnaire. Majority of the respondents are female compared to the male counterpart and majority are above 20 years of age. $61 \%$ of the respondents have limited programming skill.

Table II reflects the students' overall learning styles and it is noticed that predominant styles are convergers and assimilators compared to divergers and accommodators.

TABLE I: SHOWING DEMOGRAPHICAL \& OTHER DATA

\begin{tabular}{ccc}
\hline Variable & Descriptions & Percentage \\
\hline \multirow{2}{*}{ Gender } & Male & $38 \%$ \\
& Female & $62 \%$ \\
Age & Above 20 & $92 \%$ \\
& Below 20 & $8 \%$ \\
How to rate your & Very little & $31 \%$ \\
programming & Average & $61 \%$ \\
skill? & Above average & $8 \%$ \\
Programming & Very weak & $23 \%$ \\
skill in C & Weak & $31 \%$ \\
& Average & $46 \%$ \\
Programming & Very weak & $23 \%$ \\
skill in C++ & Weak & $31 \%$ \\
& Average & $46 \%$
\end{tabular}

\begin{tabular}{|c|c|c|}
\hline $\begin{array}{l}\text { Programming } \\
\text { skill in Java }\end{array}$ & $\begin{array}{c}\text { Weak } \\
\text { Average } \\
\text { Good }\end{array}$ & $\begin{array}{l}16 \% \\
69 \% \\
15 \%\end{array}$ \\
\hline $\begin{array}{l}\text { Time student } \\
\text { spent per week } \\
\text { outside the } \\
\text { lecture/tutorial/pr } \\
\text { actical }\end{array}$ & $\begin{array}{l}\text { Less than } 2 \text { hours } \\
\text { From } 2 \text { to } 4 \text { hours } \\
\text { More than } 4 \text { hours }\end{array}$ & $\begin{array}{c}50 \% \\
42 \% \\
8 \%\end{array}$ \\
\hline $\begin{array}{l}\text { Should students } \\
\text { be given an } \\
\text { aptitude test } \\
\text { before enrolling } \\
\text { to computer } \\
\text { studies? }\end{array}$ & $\begin{array}{c}\text { Neutral } \\
\text { Positively }\end{array}$ & $\begin{array}{l}69 \% \\
31 \%\end{array}$ \\
\hline $\begin{array}{l}\text { Assessment of } \\
\text { difficulty level }\end{array}$ & $\begin{array}{l}\text { No background in computing } \\
\text { \& programming } \\
\text { Unrelated to the subject and to } \\
\text { working conditions } \\
\text { Examples are difficult to } \\
\text { understand } \\
\text { Theoretical concepts are } \\
\text { difficult to understand } \\
\text { Less time for practice at lab }\end{array}$ & $\begin{array}{l}38 \% \\
40 \%\end{array}$ \\
\hline $\begin{array}{l}\text { Identify weaker } \\
\text { area in } \\
\text { Programming }\end{array}$ & $\begin{array}{c}\text { In understanding problem and } \\
\text { programming specifications } \\
\text { In designing program logic } \\
\text { In understanding language } \\
\text { syntax } \\
\text { In coding \& writing program }\end{array}$ & $54 \%$ \\
\hline
\end{tabular}

TABLE II: COHORT OF STUdENTS IN PROGRAMMING ClASS \& THEIR

\begin{tabular}{lc}
\multicolumn{2}{c}{ LEARNING STYLES } \\
\hline Diverging & $15 \%$ \\
Assimilators & $23 \%$ \\
Converging & $54 \%$ \\
Accommodators & $8 \%$ \\
\hline
\end{tabular}

The data was analyzed by using Chi-square distribution which is non-parametric data analysis techniques used for categorical data. We used chi-square test for independence or relatedness for the analysis of relationship between categorical variables given in contingency or crosstabulation format. Based on cross-tabulation row and column to decide degree of freedom such as $(r-1)(c-1)$ to calculate Pearson Chi-square Statistic at appropriate significance to accept and reject the hypotheses [47]. Therefore, the data analyzed on the basis of gender is provided in Table III which further indicates that majority of the female are convergers and more males are assimilators. The non-parametric correlation (Kendell's tau is significant with $p=0.031$ ) further explains that gender and learning style are dependent and there exists a relationship between gender and learning style.

TABLE III: RESULT OF STUDENTS' LEARNING STYLE AND GENDER Diverging Assimilating Converging Accommodating

\begin{tabular}{ccccc} 
Male & $0 \%$ & $15 \%$ & $23 \%$ & $0 \%$ \\
Female & $15 \%$ & $7 \%$ & $31 \%$ & $7 \%$ \\
\hline \multicolumn{4}{l}{ Pearson Chi-Square Statistic $\left(\chi^{2}=11.85\right), d f=3$, Asymp. Sig $(P<0.05)$}
\end{tabular}

Finally in order to find the relationship between programming results and the students learning styles, the non-parametric Chi-square test was conducted to assess its independency or relatedness between the categorical data. The result is shown in Table IV. 
TABLE IV: Result OF CHI-SQUARE LEARNING STYLE AND PERFoRMANCE IN PROGRAMMING

\begin{tabular}{ccc}
\hline & Pass/credit & Fail \\
Divergers & $0 \%$ & $15 \%$ \\
Assimilators & $15 \%$ & $8 \%$ \\
Convergers & $39 \%$ & $15 \%$ \\
Accommodators & $1 \%$ & $7 \%$ \\
\hline Pearson Chi-Square Statistic & $\left(\chi^{2}=7.86\right), d f=3$, Asymp. Sig $(P<0.05)$
\end{tabular}

By examining the observed cell frequencies, we can conclude that there exists a difference between convergers and assimilator learners and their performance in programming. Since the $39 \%$ of the students with converging learning style passed as compared to $15 \%$ of the students with assimilating learning style.

\section{DISCUSSION}

Table I data confirms that majority of the students falls in assimilating and converging learning style is in line with the study of Campbell \& Johnstone [22] who have also noted that $42 \%$ are assimilators and $46 \%$ are convergers. This further indicates that cohort of our degree students are more skeptical in learning through watching, doing and thinking. In other words, they are abstract thinkers rather than being concrete experience thinkers. Similarly, the data in Table 4 further shows that students who are abstract thinkers (convergers and assimilators) shows they perform better in their programming examinations. Our results therefore support Rasmussen and Davidson-Shivers, [31]; Bostrom, Olfman and Sein, [32] and $\mathrm{Wu}$, Dale and Bethel [33] who reported that convergers and assimilators individuals are successful in learning computers and programming. Our findings support Campbell and Johnstone [22] that there was who showed a significant difference between abstract and concrete thinkers. These results also confirm that abstract thinkers (convergers and assimilators) perform better in examination than concrete thinkers (accommodators and divergers). These results further support Allert [21]; Goold and Rimmer [48] and Pillay and Juggo [49] who stated that assimilators (abstract thinkers) did better than concrete thinkers. However, our results partially support Byrne and Lyons [50] who concluded that although learning style was not significant however, the convergers are the one who had selected the programming as a course of their study. Findings are in contrast to Gomes and Mendes [51] who found no correlation between the students' achievement and learning style of first year programming students.

It is useful to understand the significant learning style as it helps in designing teaching and learning strategies. Convergers believe on doing and thinking so the learners with this style of learning are good in solving problems and using their learning to find solutions to practical issues. Similarly, assimilators believe on watching and thinking and prefer for concise and logical approach. For these learners ideas and abstract concepts are more important than people. These learners who have this style of learning are more attracted to logically sounded theories and then proceed to the practical importance. This learning style is more effective for learners pursuing their career in information systems and other pure science subjects. From the data in Table IV we may conclude that converger's students are better than assimilators in relation to their overall pass achievements.

In order to answer the third research question as to explain the relationship between the gender and student learning style as provided in Table III. The result of Chisquare test showed significant difference in the learning style along four dimensions between males and females. Our results however, were in contrast with Zulkernan et al. [52] who showed no differences in learning style based on gender. The results however, supported W-Fat [39] and Wang and Chen [41] who found that participants' learning style and gender consciousness significantly affected the students' project performance. The pedagogical implications in the end further provide the answer for fourth and last research question.

\section{CONCLUSION}

The study has fulfilled all the four objectives. The findings of this study have shown that the programming students' predominant learning style is reported as convergers and assimilators. It has also revealed that students' learning styles have significant influence on students' academic performances. Finally, the gender was found to have significant influence on students' performance. In addition, the relationship between the learning styles and failing students could not be confirmed.

The learning style in this research was measured using Kolb LSI which was widely used in the academic research, the preferred learning styles of each students' could not be clearly identified based on a single preferred learning style as students might adopt more than one learning style [40].

Limitations: The study is not free from its weaknesses. The sampling here was from the population with small sample size so it was not extensive but this was due to the research design covering a cohort of student for this study. Secondly, all the data for this study came from self-report survey conducted at a single point in time. It is possible that common method variance influences the results and that data collected on different times or through different methodologies could produce different results. Thirdly, the results from this study only provide a direction so any generalization should be made with caution.

\section{Pedagogical Implications}

Identifying learners' stronger learning styles help educators understand what learners' information processing habits are and how they perceive, think, remember and solve problems [53]. Previous studies concluded that matching learners' learning styles with instructional deliverables and strategies enhanced learners' performance and suggested that it might be difficult for learners to change their learning styles, whereas learning strategies could be adapted by the learners and changed through teaching [41], [54].

This study has found that the majority of the programming students are convergers and assimilators. However, there are students in the class who belong to second category as divergers and accommodators. Although the majority of the students who has shown pass results which belong to first category, therefore it is very important 
for the facilitators and lecturers to devise their lesson plans and teaching/learning strategies for the benefits of all types of learners. For example, learners with converging learning styles are good in solving problems so for them the best strategy is to engage the learners into case study approach and lecturer should use their learning to find solution to practical issues. The role of the lecturer in this case, will be more like a coach or facilitator. The assimilating learners prefer readings books, listening to lecturers and exploring analytical model. So for this type of students, the lecturer can stimulate them through lecture, providing them with more hands-on, supplemented books, Web source and simulation exercises and here the lecturer's role will be more like an expert.

To improve the learning style for weaker students in the second group such as divergers and accommodators the best teaching learning strategies that lecture can design. For divergers teaching/learning strategies that respond to the learners as how course material relates to either with past experience or with their interest in future career. The role of the lecturer in this case will be more like a motivator. Finally, in order to help the accommodators, the lecturers should focus on designing learning strategies that help the learners to apply the programming in new situations to solve real problems. To be more effective, the lecturer should provide maximum opportunities to the students to discover the things for themselves. This can be accomplished by encouraging students to do case study solution to encourage discovery.

From this study, it can be emphasized that knowing students' preferred learning style is really an important aspect for the facilitators/lecturers in designing the pedagogical strategies for individual students. In addition, knowing students' preferred learning style helps to overcome the predisposition of many lecturers who treat students with one style of teaching to all. So lecturers must try to match students' learning style with their teaching/lecturing approaches. Thus motivate more students to achieve their academic goals. Under the conventional teaching methods, lecturer emphasize on just simple lecturing as a mode of delivery which might not be effective. Therefore, lecturers should use multiple modes of information. We agree with Gomes et al. [55] who had made suggestions that teaching strategies should support learning styles of all the students. Lecturers should not concentrate on syntactic details of programming language rather should focus on problem-solving approach using a programming language which should further be coupled with case study methodology. Therefore it is suggested that multiple mode of delivery or methodologies such as lecturing, small group discussion, active participation of the learners by doing more hands-on, simulation software, clear and well-structured presentations, video clips, supporting reading materials, case study examples, and giving more practice in problem-solving exercises will be beneficial in helping the learners to enhance their learning process. Further learners can also get benefits by being aware of their learning style and by promoting self-awareness of knowing their style and learning strategies would work together in achieving the teaching/learning objectives.

Recommendations: It is recommended to all the lecturers (even with $\mathrm{PhD}$ ) in Higher Institutions and universities to attend a short course or workshop on different learning styles and methodologies to impart knowledge to the students. At time, even a senior lecturer with vast experience and knowledge could not impart the knowledge effectively. Just like asking a young lecturer who is left-handed to use his right hand definitely it would be chaotic.

\section{REFERENCES}

[1] T. L. Lenox, C. R. Woratschek, and G. A. Davis, "Exploring declining CS/IS/IT enrolment," in Proc. ISECON 2005, Columbus, Ohio, USA, 2005, vol. 22.

[2] U. G. Gupta and L. E. Houtz, "High school student's perception of information technology skills and careers," Journal of Industrial Technology, vol. 16, no. 4, pp. 1-8, 2000.

[3] D. Dunning, K. Johnson, J. Ehringer, and J. Kruger, "Why people fail to recognize their own incompetence?" Current Directions in Psychological Success, vol. 12, no. 3, pp. 83-87, 2003.

[4] W. J. McKenzie, Beyond Technology: Questioning, Research and the Information Literate School, I.FNO Press: Bellingham, 2002.

[5] M. E. Lockhead and E. B. Mandinach, "Trends in educating computing: decreasing interest and changing focus of instruction," Information Technology and Education, vol. 15, no. 5, pp. 21-26, 1986.

[6] R. Lister and J. Leaney, "Introductory programming criterionreferencing and bloom," ACM-SIGCSE Bulletin, vol. 35, no. 1, pp 143-147, 2003.

[7] T. Jenkins, "On the difficulty of learning to program," in Proc. the $3^{\text {rd }}$ Annual LTSN_ICS Conference, Loughborough University, UK, August, 2002, pp. 53-58.

[8] C. Y. Wei, "Relationship between learning style and achievement of form four students in the subject of basic economics at a school in Kajang," Master dissertation, The University of Malaysia, Bangi Selangor, Darul Ehsan, Malaysia, 2009.

[9] M. Yilmaz-Soylu and B. Akkoyunlu, "The effect of learning styles on achievement in different learning environments," Turkish Online Journal of Educational Technology, vol. 8, no. 4, pp. 43-50, 2002

[10] K. S. Hong and K. L. Chan, "Effects of learning styles on undergraduates' attitudes, navigational patterns and use of navigational tools in hypermedia based learning," The Electronic Journal on Information Systems in Developing Countries, vol. 2, no. 3, pp. 1-11, 2000.

[11] S. Garf et al., "Supporting teaches in identifying student's learning styles in learning management systems: An automatic prudent modeling approach," Educational Technology \& Society, vol. 12, no. 4, pp. 3-14, 2009.

[12] J. Reid, "The learning style preferences of ESL students," TESOL Quarterly, vol. 21, no. 1, pp. 87-111, 1987.

[13] R. Zhenhui, "Matching teaching styles with learning styles in East Asian context," The Internet TESL Journal, vol. 7, no. 7, July 2001.

[14] S. W. Too, "Student's learning style and their academic achievement for taxation course - A comparison study," in Proc. the $2^{\text {nd }}$ International Conference of Teaching and Learning (ICTL), Malaysia, 2009.

[15] J. W. Keefe, Student Learning Style: Diagnosing and Prescribing Programs, Reston, VA: National Association of Secondary School Principals, 1979

[16] N. D. Fleming and C. Mills, "Not another inventory, rather a catalyst for reflection," To Improve the Academy, vol. 11, pp. 137, 1992.

[17] D. A. Kolb, Experiential Learning: Experience as the Source of Learning \& Development, Englewood-Cliff, NJ: Prentice-Hall, 1984.

[18] P. Honey and A. Mumford, The Manual of Learning Styles, Maidenhead: Peter Honey, 1982.

[19] R. Felder and R. L. Silverman, "Learning and teaching styles in engineering education," Engineering Education, vol. 78, pp. 674-681, 1988.

[20] I. B. Myers, The Myers-Briggs Type Indicator Manual, Princeton, NJ: The Educational Testing Services, 1962.

[21] J. Allert, "A companion technology approach to CS1, handheld computers with concept visualization software," in Proc. $4^{\text {th }}$ IEEE International Conference in Advanced Learning Technologies (ICALT), Joensuu, Finland, August 2004, pp. 385-389.

[22] V. Campbell and M. Johnstone, "The significance of learning style with respect to achievement in first year programming student," in Proc. Australasian Software Engineering Conference (ASWEC 2010), Auckland, New Zealand, 2010, pp. 165-170.

[23] C. Mainemelis, R. E. Boyatzis, and D. A. Kolb, "Learning styles and adaptive flexibility: testing experiential learning theory," Management Learning, vol. 33, pp. 5-33, 2002. 
[24] R. Loo, "Confirmatory factor analysis of Kolb's learning style inventory (KLSI-1985)," British Journal of Educational Psychology, vol. 69 , pp. 213-219, 1999.

[25] N. D. Fleming. (2012). VARK: A guide to learning styles. [Online]. Available: learn.com/english/page.asp?p_questionnaire

[26] W. B. James and W. E. Blank, "A comparison of adult's perceptual learning style and their educational level," Mountain Plains Adult Association Journal, vol. 19, pp. 11-21, 1991.

[27] L. C. Sendil, "The effects of science student teachers' academic achievements, their grade levels, gender and type of education they are exposed to their kolb learning styles: Case of Mugla University Turkey," Procedia Social and Behavioral Science, vol. 1, pp. 1853 1857, 2009.

[28] R. Yusof, N. Othman, and F. Karim, "Strategi pembelajaran pengalaman model Kolb dalam pendidikan, perakaunan," Journal Pendidikan Malaysia, vol. 30, pp. 112-128, 2005.

[29] W. F. T. Wing and A. K. Y. Hoi, "Exploring the effects of gender and learning styles on computer programming performance: Implications for programming pedagogy," British Journal of Educational Technology, vol. 40, no. 4, pp. 696-712, 2009.

[30] A. F. Gregorc, Inside Styles: Beyond the Basic. Gregorc Associates, Columbia, CT, 1985

[31] K. Rasmussen and G. Davidson-Shivers, "Hypermedia and learning styles: Can performance be influenced?' Journal of Educational Multimedia and Hypermedia, vol. 7, pp. 291-308, 1998.

[32] R. P. Bostrom, L. Olfman, and M. K. Sein, "The importance of learning style in end-user training," MIS Quarterly, vol. 14, pp. 101$119,1990$.

[33] C. C. Wu, N. B. Dale, and L. J. Bethel, "Conceptual models and cognitive learning styles in teaching recursion," in Proc. SIGSCE, Atlanta, USA, 1998.

[34] M. Ben-Ari, "Constructivism in computer science education," Journal of Computers in Mathematics and Science Teaching, vol. 20, no. 1, pp. 45-73, 2000.

[35] P. Machanick, "A social construction approach to computer science education," Computer Science Education, vol. 17, no. 1, pp. 1-20, 2007.

[36] A. Alharbi, D. Paul, F. Henskin, and M. Hannaford, "An investigation into learning styles and self regulated learning strategies for computer science students," in Proc. ASCILITE, Hobart, Australia, 2011.

[37] T. Yeboah and A. Sarpong, "A study to investigate learning a style that has higher grade achievement in computer programming," Journal of Engineering, Computers and Applied Science (JEC\&AS), vol. 1, no. 3, pp. 33-38, 2012.

[38] S. E. Severiens and G. T. M. T. Dam, "Gender differences in learning styles: A narrative review and quantitative meta-analysis," Higher Education, vol. 27, no. 4, pp. 487-501, 1994.

[39] L. W-Fat, "Exploring the relationship among gender, learning style, mental model and programming preferences: Implications for learning and teaching of computer programming," $\mathrm{PhD}$ dissertation, The University of Hong Kong, 2009.

[40] C.-Y. Wei, Y.-H. Hoo, and J. See. (2011). Relationship between learning style and content based academic achievement among tertiary level students. [Online]. Available: http://www.curtin.edu.my/TL2011/download/papers/nonrefereed/Rela tionship_between_learningstyle_contentbased_academic_achievemen t_among_Tertiary_Students.pdf

[41] L. C. Wang and M. P. Chen, "The effects of learning style \& gender consciousness on novice's learning from playing educational games," Knowledge Management \& E-Learning: An International Journal, vol. 4, no. 1, pp. 63-77, 2012.

[42] N. M. Norwawi, S. F. Abdusalam, C. F. Hibadullah, and B. M. Shuaibi, "Classification of students' preference in computer programming course according to learning style," in Proc. Conference on Data Mining \& Optimization, Oct, Selangor, Malaysia, 2009.

[43] R. M. Felder and R. Brent, "Understanding student differences, Journal of Engineering Education, vol. 94, no. 1, pp. 57-72, 2005.

[44] L. C. D-Carmo, M. J. Marcelino, and A. I. Mendes, "The impact of learning styles in introductory programming learning," in Proc. International Conference on Engineering Education, ICEE-Portugal, 2011.

[45] F. Coffield, D. Moseley, E. Hall, and K. Ecclestone, "Learning styles and pedagogy in post-16 learning: A systematic and critical review,' Learning Skills Research Center, Dept of Education \& Skills, London, UK, 2004.

[46] D. S. Moore and G. P. McCabe, Introduction to the Practice of Statistics, $5^{\text {th }}$ edition, USA: W. H. Freeman \& Company, 2005.

[47] R. Levin and D. Rubin, Statistics for Management, $7^{\text {th }}$ Edition, Princeton, NJ: Prentice-Hall, 1996.

[48] A. Goold and R. Rimmer, "Indicators of performance in first-year computing," ACM SIGCSE Bulletin, vol. 32, pp. 39-43, 2005.

[49] N. Pillay and V. Juggo, "An investigation into student characteristics affecting novice programming performance," SIGCSE Bulletin, vol. 37, pp. 107-110, 2005.

[50] P. Byrne and G. Lyons, "The effect of student attributes on success in programming," ACM SIGSE Bulleting of the Proceeding of the $6^{\text {th }}$ Annual Conference on Innovation and Technology in Computer Science Education, vol. 33, no. 3, p. 52

[51] A. Gomes and A. Mendes, "A study on student's characteristics and programming learning," in Proc. World Conference on Educational Multimedia, Hypermedia and Telecommunications, Chesapeake, VA: AAC, 2008, pp. 2895-2904.

[52] I. A. Zualkernan, J. Allert, and G. Z. Qadah, "Learning styles of computer programming students: A Middle Eastern and American comparison," IEEE Transaction on Education, vol. 49, no. 4, pp. 443 450, 2006.

[53] S. Messick, "The matter of style, manifestations of personality in cognition learning \& teaching," Educational Psychologist, vol. 29, no 3, pp. 121-136, 1994.

[54] N. Ford and S. Y. Chen, "Matching/mismatching revisited: An empirical study of learning and teaching styles," British Journal of Educational Technology, vol. 32, no. 1, pp. 5-22, 2001.

[55] A. Gomes, S. Alvaro, C. Lilian, and A. J. Mendes, "Learning styles in an e-learning tool," in Proc. International Conference on Engineering Education (ICEE), University of Coimbra, Coimbra, Portugal, 2007.

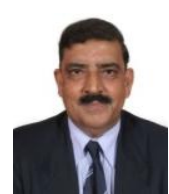

Afzaal H. Seyal is a senior lecturer at the Computing \& Information Systems Programme Area, Faculty of Business \& Computing. He has twenty-four years of teaching, research and consulting experience in information systems/info tech. He has published over 80 papers in the leading A-class journals in Information Systems such as Journal of Global IT Management, Electronic Markets, Behavior and Information Technology Journal of EC in Organizations, Journal of End-User Computing and Information \& Management in addition to the proceedings of various national, regional and international conferences in USA, Australia, Europe, Hong Kong, and Malaysia.

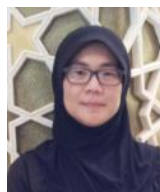

Yeo Sy Mey is a senior lecturer at the Computing \& Information Systems Programme Area, Faculty of Business \& Computing. She is also the director of ICT Centre. She has been teaching in the programme are for almost 20 years especially in programming modules. Programming language include $\mathrm{C}, \mathrm{C}++$, Java, C\# and Python. Her research interest incudes programming, cloud computing and computer networking.

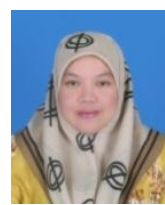

Degree.

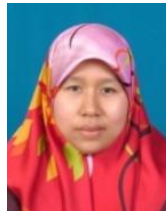

Nor Zainah Siau is a senior lecturer in the Computing and Information System Programme Area at Institu Teknologi Brunei, Brunei Darussalam. She received the BSc degree from Teesside University, UK in 1998 and the MSc degree from Coventry University in 2004. She is currently in the final stage of her $\mathrm{PhD}$ studies at Loughborough University, UK. Her research interests include web information extraction, genetic programming and database management.

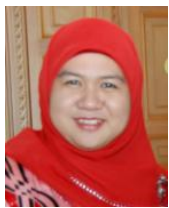

Armanadurni Abdul Rahman is a lecturer at the Computing \& Information Systems Programme Area, Faculty of Business \& Computing. She is specialized in computer networking and she is the coordinator for CISCO academy in ITB. She has been teaching in computer network area for more than 5 years. 